University of Louisville

ThinkIR: The University of Louisville's Institutional Repository

\title{
Female political leadership in the Southern Cone : roles and perceptions of women in formal politics.
}

\author{
Rosslyn Elliott Steinmetz \\ University of Louisville
}

Follow this and additional works at: https://ir.library.louisville.edu/honors

Part of the Political Science Commons

\section{Recommended Citation}

Steinmetz, Rosslyn Elliott, "Female political leadership in the Southern Cone : roles and perceptions of women in formal politics." (2013). College of Arts \& Sciences Senior Honors Theses. Paper 24. http://doi.org/10.18297/honors/24

This Senior Honors Thesis is brought to you for free and open access by the College of Arts \& Sciences at ThinkIR: The University of Louisville's Institutional Repository. It has been accepted for inclusion in College of Arts \& Sciences Senior Honors Theses by an authorized administrator of ThinkIR: The University of Louisville's Institutional Repository. This title appears here courtesy of the author, who has retained all other copyrights. For more information, please contact thinkir@louisville.edu. 


\section{Female Political Leadership in the Southern Cone: \\ Roles and Perceptions of \\ Women in Formal Politics}

By

Rosslyn Elliott Steinmetz

Submitted in partial fulfillment of the requirements for Graduation summa cum laude and

for Graduation with Honors from the Department of Political Science

University of Louisville

May, 2013 


\section{Foreword}

Two years ago I was not even aware of the existence of gender quotas in Latin America, but in 2011 I went to study in Buenos Aires, Argentina for one year. I took a course on the history of gender in Latin America, and I became fascinated with the subject of women's participation in politics. It was an exciting time to study political women in Argentina because Cristina Fernández de Kirchner, the first woman elected president of Argentina, was campaigning for reelection. During my first semester of study at the Universidad Torcuato di Tella I wrote a class paper on the relative lack of tangible progress toward the improvement of women's status in Latin America despite the rise of the number of women present in formal political institutions. I concluded that persistent gender discrimination in both society and political establishments continued to limit the ways that women could gain access to political offices and wield the power vested in those positions.

However, in early 2012 I had the good fortune to intern briefly for Diputada Gladys Gonzalez, a congressional representative of the province of Buenos Aires, and that experience changed my mindset. I began to see that some women focused on the less powerful or prestigious subjects of governance, such as education and family planning, not because the men forced them to, but because they sought to enact policy changes that would positively alter the lives of women in Argentina. They saw the opportunity to make real progress that would affect women's daily lives, helping them to create better lives for themselves and their families. This inspired me to undertake this research project to investigate the interaction between public perceptions of women in the Southern Cone and the roles that women undertook once they gained access to public office. This work is the culmination of my findings. 


\section{Introduction}

Women in developing countries have become the focus of significant research in recent years, which is not surprising given that one of the eight Millennium Development Goals established by the United Nations (UN) in 2000 is to "promote gender equality and empower women." Research on gender issues in developing nations has been particularly popular since the formation of the United Nations Entity for Gender Equality and the Empowerment of Women (also known as UN Women) in 2010 as an attempt to streamline UN activities on gender equality. While the media tends to focus attention on the important areas of female health and economic interests, another significant goal that the UN has been working toward is the enhancement of women's roles in political decision-making. This area deserves extensive consideration because policymaking is an important activity that has a direct and lasting impact on women's lives, and politics continues to be a domain in which gender inequality remains prominent (Hughes 2009).

Latin America is a region that has received substantial academic attention because it leads the world in the adoption of gender quota legislation and the election of female heads of government (Htun 2002). Despite political strides such as the rising phenomenon of $l a$

presidenta, Latin America has not yet risen above the legacy of machismo to enter an era of gender equality. This paper focuses on the two major countries of the Southern Cone Argentina and Chile - as states of particular interest. Argentina and Chile share similar political histories of polarizing party politics, caudillo leaders, political mobilization of labor unions, military dominance, and state-sponsored terrorism. Like many other countries in the region, both Argentina and Chile underwent processes of redemocratization after emerging from dictatorships in the latter half of the twentieth century. Women played a leading role in challenging the military dictatorships in these countries and promoting successful transitions to democratic 
governance (Hensman 1996). Although Argentinean and Chilean women were instrumental in the struggle to re-democratize their countries, and despite their efforts to incorporate women and gender interests in the new governments, institutional and sociocultural barriers to women's participation in democratic decision-making persist. These barriers hinder women's abilities to gain access to and exercise power in ways that could create substantive change, especially in gender issues. This study will examine the influence of traditional views of gender on the roles of women in politics, and how women's presence and actions in politics may be affecting conventional perceptions of women in the Southern Cone.

The roles and perceptions of women in Argentinean and Chilean politics have been influenced by the international context of movements for gender equality, but they are rooted in the historical development of each country's politics and culture, and they continue to be shaped by the structures of the political and electoral systems in place today. Of notable import is the different transitional processes adopted by each country, since they have shaped the existing democratic institutions and the boundaries of gender politics and resulted in profound differences between the two (Gray 2003). In order to understand the current roles and perceptions of women in politics in the Southern Cone, it is necessary to explore these dominant factors and situate these case studies within the cultural, international, and historical contexts.

\section{Gender Culture}

While the problem of gender underrepresentation has been universal as a result of gender discrimination across cultures and around the world, the framework of gender culture in Latin America is uniquely distinct and pervasive, and therefore merits targeted discussion. Machismo is a term known throughout the world, but the actual meaning of the concept is not universally understood. The Merriam-Webster English dictionary defines machismo as simply "a strong 
sense of masculine pride: an exaggerated masculinity" (2013). The English encyclopedia definition goes a step further to explain the perception of power associated with masculinity. It states that machismo involves "a minimal sense of responsibility and disregard of consequences"; "there is a supreme valuation of characteristics associated with the masculine" (Mirriam-Webster 2013). The Spanish-language definition from the Real Academia Española recognizes the power dynamics inherent in machismo, which it defines as an "attitude of superiority, domination, or abuse of power of men over women" (translated by author from Real Academia Española 2001). Academic definitions of machismo reflect an even deeper understanding of the term in its cultural and political implications, and are therefore far more useful for this discussion. Paxton and Hughes refer to machismo as the extreme male ideal for appropriate gender behavior; it "calls for arrogance and sexual aggression in the relationships between men and women" and links cultural standards, such as having a large family and women staying in the home, to male virility $(2007,232)$.

However, gender culture in Latin America is not based exclusively on a constructive definition of male behavior which in itself prescribes the norms for female behavior. Marianismo could be described as the female counterpart to machismo. It is explicitly based in the doctrine of the Catholic Church, which has played a dominant role in the development of political and social cultures in Latin America. Marianismo is based in the symbol of the Virgin Mary as the ideal for the female gender: a pure, selfless mother. The selfless mother is the supreme moral figure in Latin American cultures (Luna 2003, 59). The selfless mother is simultaneously spiritually strong and submissive to men, and therefore "dependent, timid, and conformist" (Paxton and Hughes 2007, 232). In the political context, marianismo denotes "an extremely aggressive or 
competitive style of speech and a condescending or patronizing attitude towards women" (Franceschet 2001, 215).

Marianismo and machismo each possess both positive and negative aspects. The positive side of machismo is the caballero, the gentleman who is the "true protector" of his wife and family (Gil and Vazquez 1996, 3). Gil and Vazquez posit that marianismo is about "about sacred duty, self-sacrifice, and chastity. About dispensing care and pleasure, not receiving them. About living in the shadows, literally and figuratively, of your man-father, boyfriend, husband, sonyour kids, and your family" $(1996,4)$. Marianismo once afforded benefits such as veneration to women who complied with its norms; however, the system that once protected women under these behavioral rules no longer exists. Women are far more often forced into servant-like submission and prevented from seeking self-validation of any form (Gil and Vazquez 1996).

These gender norms explain the historical exclusion of women from politics (or any form of public life, for that matter) in Latin America. Even as women have gained more access to the political sphere, machismo has continued to define the structures that determine women's access to politics and marianismo continues to limit women's opportunities for political participation. Marianismo suggests that women should not partake in politics because it is an inherently corrupt practice. This serves to promote the idea that women should only mobilize politically in the case of a social crisis, and they generally justify their interventions on the basis of their status as mothers (Feijoó and Nari 1994, Jaquette 1997; Shepherd 2010).

Essentially, the most prominent manifestation of machismo and marianismo is the division of society into two spheres: the visible public and political realm belonging to men and the invisible, private sphere in which society expects women to reside. These concepts will inform the particular discussions of women in political leadership in Argentina and Chile during 
their respective dictatorships and transitions to democracy, as well as the current features of political women in the Southern Cone.

\section{International Women's Movements}

The first wave of feminism during the late nineteenth and early twentieth centuries focused on the formal incorporation of women in politics, meaning women's access to the political process through the right to vote, as its main objective. While there were some attempts at international organization of women's movements around this time, most mobilization occurred on the national scale and was defined by differences in the class, location, and race of women. Suffrage movements in Latin America were mostly small, and most members were educated, urban, middle-class women who tended to be white (Paxton and Hughes 2007). Women's education was an important factor in mobilization for women's rights. Westernized males in Latin America raised levels of basic education for women, and educated women then led the charge to fight for access to higher education and the right to vote. This was important because a major argument against women's suffrage was that women lacked the necessary qualities (such as education) to participate in government (Franceschet and Piscopo 2012). The Catholic Church and the political right, two important political actors, also opposed this step toward women in politics, which will be discussed independently in the cultural context of machismo and marianismo.

In Chile in 1931, women won the right to vote in municipal elections, but full suffrage was not granted until 1949. The charge for women's suffrage in Argentina was led by the overwhelmingly popular First Lady Eva Perón, the first woman to cast a vote in the country in 1947. Chile and Argentina joined many countries and adopted full suffrage after the creation of the UN. The UN Charter, signed in 1945, supports equal political rights, and in 1946 the UN 
General Assembly issued an official recommendation to grant women the same political rights as men (Paxton and Hughes 2007). Although women gained legal political rights in most countries around this time, the mere establishment of formal (legal) access to politics did not signify that women could actually exercise those rights.

After achieving the goal of suffrage, women's movements tended to wither and did not emerge with strength again until the 1970s. The UN designated 1975 as International Women's Year (IWY) and held its first official international women's conference in Mexico City that year (Antrobus 2004). Women's political participation was one of many topics discussed at the conference, which revealed that one year was simply not enough time to dedicate to the needs and interests of women, so the UN designated an entire decade for women. The discussions between women from different countries fostered a growing recognition among them that the "personal is political" (Antrobus 2004, 45-48). In other words, “women's concerns" or personal concerns are political concerns. Significantly, this realization reveals the connections between women's experiences in liberation movements, such as the Chilean and Argentine fights for democracy, and their experiences as women: marginalized and powerless. The 1979 UN Convention on the Elimination of All forms of Discrimination Against Women (CEDAW) marked the first resolution to promote gender quotas as a strategy "to advance women's integration into education, the economy, politics and employment" (UN 2000). In other words, CEDAW specifically advocates the use of temporary gender quotas to promote gender mainstreaming in all areas, including elected and non-elected government positions. The UN has since reaffirmed its commitment to and efforts toward the achievement of gender equality in political participation. In fact, the UN included that goal in the 2000 Millennial Development Goals (UN 2000). 
Achieving gender equality is imperative not only because it is a basic human right, but also because it stimulates the economy, thus promoting development, peace, and security (UN Women 2011a). Activists argue that increasing female representation in political entities and governing bodies amplifies women's voices and ensures that their needs are met. Various arguments have been used to support the position that low levels of descriptive, or numerical, representation of women in the governing bodies of formal politics constitute a problem. First, political positions are important. Accordingly, the people who fill these positions make decisions that affect the lives of the public, political power is a valuable good, and political offices are positions of power and authority that indicate who in society is legitimated (Paxton and Hughes 2007, 3). Two major categories of arguments for the incorporation of women in these political posts offer a response: justice arguments based on what is fair and utility arguments, which posit that the inclusion of women enhances the quality of representation and political deliberation.

Women make up approximately 50 percent of the population in the world, so justice would seem to suggest that women and men should be equally represented in politics. However, even today, the percentage of women in parliaments worldwide has just barely broken 20 percent (IPU 2013). The most basic form of equal representation is formal representation, discussed previously in the context of international movements for women's suffrage. Formal rights alone do not eliminate the influence of centuries of repression, or remedy the substantial social and economic inequalities that prevent historically marginalized groups such as women from taking advantage of their legal opportunities. Paxton and Hughes define equal formal representation as "the legal right to participate in politics on an equal basis with men" $(2007,8)$.

The next level of representation is descriptive representation, meaning that descriptive (demographic) similarities exist between political representatives and the constituents they 
represent. The argument for descriptive representation rests on the idea that racial, ethnic, and in, this case, gender groups are uniquely suited to represent themselves in politics (Paxton and Hughes 2007). It is salient to clarify that this is not an essentialist argument that assumes that all women share a common identity; it reflects the idea that women, because of their gender experiences and gendered social positions, share some common interests and concerns.

The third form of representation is substantive, in which (women's) interests must actually be presented and supported in the political arena. Proponents of substantive representation argue that the presence of women in politics is a necessary, but not a sufficient, condition for women's interests to be served.

Paxton and Hughes present two central types of arguments for women's political representation (2007). Justice arguments for women's inclusion in politics focus on women's equality to men, while utility arguments emphasize the ways that the practice of politics can be improved by the inclusion of women. On a basic level, these arguments emphasize that since women constitute 50 percent of the population, excluding women from politics means automatically eliminating half of the pool of talent that could serve those positions. If a country really wants the best for its people, it should draw its leaders from the entire population. Furthermore, the representation of all members of society can help to ease social tensions and stabilize democracy (Paxton and Hughes 2007; Htun 2002).

Another significant utility argument points to women's differences from men as a reason why they should be a part of politics. It states that although women differ from men, they should be valued equally. The fact that they are different makes them uniquely qualified to enhance the quality of representation and deliberation in democracies. The presence of women can increase the overall diversity of ideas, values, and political styles represented within political process, 
thus strengthening democracy and representing a wider range of societal interests and options for policy solutions. Research has also shown that women tend to be more cooperative and peaceful and therefore have a different way of doing things that might improve the ways that men have used to govern societies throughout history (Hunt and Posa 2001; Skjelsbaek 2001). Utility arguments are the essence of the politics of difference, which has been the foundation of the women's movements in the Southern Cone (Molyneux 2001). Variations of utility arguments tailored to each country's specific national context will be explained within the political situations of each under the section on "Historical Context".

\section{Historical Context}

\section{Argentina}

Argentina has had tumultuous political history. The first president, Bernardino Rivadavia, renounced his title in 1827 , just one year after his term began, and no one took over the post again until 1854. Hipólito Yrigoyen was the first Argentine president to be deposed, in 1930, but he was not the last: ten more were similarly removed from office. The country has been ruled by military dictatorship on more than one occasion, but the most famous period, 1976-1983, marked a span of time in which the military junta banned all (conventional) forms of political organization and launched a campaign of state terrorism commonly referred to as the Dirty War. The junta implemented harsh neoliberal economic policies and attempted to eliminate anyone it perceived as a communist subversive. The regime preached of the importance of the family as the essential unit of society, but at the same time it enacted a combination of policies that resulted in a steep decline of income and made drastic cuts to social services such as healthcare and educational opportunities that formerly had created a safety net for those families (Feijoó and Nari 1994, 111). Women were hit the hardest by these policies because they were socially 
responsible for family welfare, yet they were not able to find jobs to fulfill that role. This caused the development of self-help women's organizations designed to provide social welfare for their communities. The dictatorship affected women in various ways, and Feijoó and Nari identify three major ways that women organized in their efforts to improve their lives: the human-rights movement, mobilization to access resources necessary for their families' survival, and feminist organizations $(1994,112)$.

The best known example of women's mobilization in opposition to the dictatorial government is the Madres de la Plaza de Mayo, a group of women who united to press for information about the whereabouts or fates of their "disappeared" children. While estimates of the number of disappeared persons do vary, it is generally accepted that about 30,000 Argentines were disappeared between 1976 and 1982. They were disappeared in a very literal sense: the junta abducted union militants, students, intellectuals, and other members of society, and they were never seen alive again (Hensman 1996). The Madres, a group now known worldwide as the symbol of popular resistance, was started by 14 women who came to know each other as they were all independently searching for answers about what had happened to their children. They received no answers from the police, so they began to organize privately, in 'feminine' spaces such as tea houses, and then made the important move to bring their concerns to public attention (Shepherd 2010). The dictatorial regime allowed the Madres to organize precisely because they were women - mothers - and inherently not threatening. Beginning in 1977, women gathered every Thursday in the Plaza de Mayo, the symbolic and physical locus of state power in Argentina, to demand information about their missing children and the release of individuals who had been detained illegally. 
The Madres association was explicitly women only. They represent the phenomenon of "mobilized mothers"; these women entered into politics and the public sphere based on their feminine identity as mothers and the social responsibilities it entailed. Their political participation was a public extension of their domestic duties as mothers to defend and protect their children, responsibilities which the military junta promoted but made impossible to fulfill (Feijoó and Nari 1994; Hensman 1996). This purpose was made visible by the donning of the white headscarves as a symbol for the pañuelos, or diapers, that they had used while raising their children (Shepherd 2010). Shepherd notes the significance of the Madres wearing the white scarves as symbols of life, peace, and hope and a refusal to simply mourn the loss of their children in the traditional way $(2010,10)$.

A gender-based analysis of the Madres movement is complex because the women simultaneously accepted traditional gender norms and transformed the limiting behavioral expectations of marianismo into the justification for their political mobilization (Hensman 1996; Feijoó and Nari 1994; Paxton and Hughes 2007; Shepherd 2010). The Madres challenged the traditional expectation of feminine passivity and submission by placing themselves in public space and demanding action, but they did so in accordance with the Argentine feminine ideal of a self-sacrificing mother. The military did not originally perceive any threat in the actions of the Madres. Women were seen as apolitical because they did not participate in conventional partisan politics, but the value of their community leadership was revealed and recognized when the military junta made the traditional practice of politics impossible. The junta regarded women's meetings as "harmless gossiping" (Paxton and Hughes 2007, 234). It initially viewed their public requests on behalf of their children as supportive of the state's promotion of mothers as the essential unit of society. But the junta itself recognized the strength of the women's opposition in 
a perverse sort of way: 14 of the leading Madres themselves disappeared at the hands of the regime (Hensman 1996). The obvious hypocrisy of the military junta's willingness to act violently against peaceful mothers contributed even further to the mounting opposition to the regime and its eventual downfall.

Another women's organization that emerged and flourished under the authoritarian regime in Argentina fits into Feijoó and Nari’s second category: mobilization to secure essential family resources. The National Housewives Movement (Housewives) began in Buenos Aires as women joined together to boycott products and participate in public demonstrations against the poor quality of life caused by the military's economic policies (Feijoó and Nari 1994). It originated in 1982 as a group of middle-class women encouraging their peers to protest against the rising cost of living, but it had grown to a movement supported by thousands of women throughout the country by 1983 . The women went beyond simple requests for the means to secure a stable household to crafting an eighteen-point program for specific policy actions to achieve their goals (Hensman 1996).

Remarkably, the Catholic Church, which had historically been an actor involved in the restriction of women to traditional gender roles, actually legitimized their participation in these organizations. Women's actions in the Madres association and the Housewives' organizations maintained and reinforced the Christian ideal of womanhood; these women sustained the gender ideology of marianismo by acting out of their roles as mothers and protectors of their children (Paxton and Hughes 2007). Furthermore, the human rights implications of the issues women addressed aligned with the Church's opposition to the dictatorships (Feijoó and Nari 1994).

It is also notable that both the Madres and the Housewives organizations still exist today and continue to address public issues related to their initial concerns. As Hensman notes, these 
organizations began with very traditional 'feminine' concerns and actions, but the experience of self-organization in the public sphere during the dictatorship inevitably politicized them (1996).

Although the majority of feminist groups were dissolved after the military toppled the decaying democratic government, several explicitly feminist organizations did emerge during the years of the military dictatorship. One such group was the Alfonsina Storni Women's Association (Asociación Mujeres Alfonsina Storni, AMAS), named after the feminist Argentine writer and poet born during the nineteenth century. The AMAS 1978 platform expressed commitment to unifying women to improve their status, increasing feminine participation in economic development, and preserving peace (Feijoó and Nari 1994, 115). These objectives echo the three themes of women's movements as established in the first international conference on the status of women during the UN's International Women's Year in 1975. The General Assembly also identified these as the intentions of the UN's work on the status of women (UNDPI 2000). AMAS and other feminist groups worked to mobilize a national feminist movement dedicated to women's dignity, freedom, and justice by utilizing a variety of (politically) nonconventional means such as showing films in addition to promoting party activism.

One of the major accomplishments for women during the dictatorship was the formation of solidarity among women of different classes and races. As has been the case across the world, women in Argentina had generally been politically divided along lines of class and race, which were more closely tied to political parties than a gender identity. While some such divisions continued to exist during the dictatorship, this period of crisis brought women together to face the problems that they shared as women and contributed to the development of women's solidarity and rising gender self-consciousness (Paxton and Hughes 2007, Feijoó and Nari 1994). 
To summarize, women ironically achieved a new form of political empowerment because of the combined effect of three factors that have traditionally been the principal sources of women's political exclusion: the Catholic Church, the marianismo instructions for feminine conduct, and authoritarian regimes (Paxton and Hughes 2007, 234). Each of these factors individually still restricted women's rights, but the convergence of all three during the 19761983 dictatorship created a social and political context in which women were uniquely qualified and justified to organize for public purposes. The truly exceptional result of the military dictatorship was not a sudden acceptance of women's presence in politics, but rather the fact that the styles and purposes of women's organization were finally recognized as political for the first time. Given the complete, uncompromised demobilization of men through the prohibition of labor unions, political parties, and political protest activities, women had space to make their voices heard. Women's mobilization in opposition to the dictatorship publicized the value of their participation. Feijoó and Nari state that the three types of women's organizations prevalent during the dictatorship converged to reveal "the inescapable need to incorporate women into the process of democratization" $(1994,116)$.

As such, ironically it was during a period of harsh military dictatorship that the conditions were set for the emergence of women's mobilization and the recognition and valuation of women's political participation. But what implications did this have for the incorporation of women in the transition to democracy and the inclusion of women in the processes of Argentine politics today? The daily practice of democracy after redemocratization in 1983 has relegated Argentine women to their traditional roles and restricted their opportunities to participate in politics (Feijoó and Nari 1994, 109). This de-politicization and demobilization of women is, in part, a result of the women's own political discourse that was used to justify and 
support their participation during the dictatorship. The de-politicization is not all-encompassing. Women have made new strides toward accomplishing the goals of feminine and feminist agendas and continue to do so, but they continue to face obstacles to having their voices heard about issues that concern them, particularly in the arena of formal politics.

As was previously stated, Argentine politics during the period of transition to democracy were marked by a new awareness of the need to include women in the process of democratization. The political parties that reemerged demonstrated an acute awareness of this fact and attempted to address it by building women's sectors within the party structures, considering the demands of women, and, in the case of the smaller parties, including women in the secondary seat on the presidential ticket (Feijoó and Nari 1994). The construction of women's wings of the political parties was not a new method to appeal to women voters, but a revival of a technique used by the Partido Justicialista, also known as the Peronist party, during the late 1940s. Although the term "feminism" does not carry positive connotations in Argentine politics, the political parties did make clear efforts to address some feminist concerns. Raúl Alfonsín, the candidate of the Unión Cívica Radical (UCR) who became the first democratically elected leader since before the dictatorship, used "women-sensitive language" and even openly criticized machismo during his campaign (Feijoó and Nari 1994, 117). Both he and the Peronist candidate raised the issues of divorce, shared patria potestad (the rights and responsibilities of parents in regard to their children), and the defense of peace while on the campaign trail, thus bringing a whole new level of attention to women's issues and addressing their interests as citizens (Feijoó and Nari 1994).

In addition to courting the women's vote, the political parties were aware that they needed to build external legitimacy and present a modern, democratic image in order to receive 
much wanted support from the international community. Extending women's rights was one way that the new political leaders sought to strengthen the country's image as a transparent and inclusive democracy. Women's political rights had been gaining significant attention on the international agenda in connection with the concept of 'good governance'. Some multilateral finance agencies also required policies to support the inclusion of women in democratic process as conditions for loans (Araújo and García 2006).

Unfortunately, the male political leaders were not able to move beyond progressive rhetoric to enact the legislative changes that they had promised or actually to pull women into the decision-making process to influence the policies that affect them. They were satisfied with creating the women's wing within the party structure and appealing to women as voters and failed to include women as protagonists in the political process, instead reverting to the customary schemes to “improve women’s condition” (Feijoó and Nari 1994). This reinforced the traditional role of women in Argentine society as dictated by marianismo. This was possible, in part, because women had drawn on the conservative aspects of femininity to justify their political participation during the dictatorship. Women themselves advocated their inclusion for their role as only women. The political use of marianismo secularized the rationale for women's absence from politics: women should conform to the ideal of motherhood as the essence of femininity, and as ethical actors they should not be involved in the corrupt practice of politics (Feijoó and Nari 1994). This secularization is evident in the way that feminist organizations, which challenged some of the explicitly religious facets of marianismo, insisted on autonomy from political parties and the political system because women were above corruption.

The women's organizations themselves were severely challenged by the changing political atmosphere of redemocratization. Women had been able to thrive as political leaders 
under the repression of the dictatorship specifically because their forms of organization and mobilization were not traditionally recognized as political and men were essentially absent from the scene. They used their common identities as mothers to justify new public forms of action during that period. But the dawn of democracy eliminated the singular force against which they had united and required women to innovate new ways to address the multivariate concerns and more complex processes of democratic governance. In this sense, working toward the united and simple goal to end military rule was a far simpler task than the constructive work of establishing a completely fair and inclusive civilian peace (Feijoó and Nari 1994). Furthermore, the absence of the dictatorship as the common enemy exposed the stark differences among women.

Not only did women face the task of instituting a new democratic society, but they found themselves having to work within the framework of the traditional mode of male-constructed and male-dominated politics that had regenerated itself as the de facto style of democratic government. Political parties were reinstated, allowing men to resume their roles as political leaders who determine the configuration of political institutions and regulate who has admission to them and how they can access political operation (Feijoó and Nari 1994).

Democratic systems are far more complicated than dictatorial rule because they are composed of various institutions with controlled options for citizen input, as opposed to the monolithic presence of a dictatorial state. Women had to learn how to operate effectively to sway not just one group of people, but to influence distinct operational processes within the independent judicial, executive, and legislative branches of government. Although women failed to secure everything that they sought, they did make certain progress in some areas. Women's interests gained an official voice within the state structure during the administration of Raúl Alfonsín with the creation of the National Women's Agency (Consejo Nacional de la Mujer) 
within the Ministry of Social Action. Alfonsín's successor, President Carlos Menem, went a step further and helped to create the National Council of Public Policies, which passed a law against gender discrimination and promoted the formation of women's areas within provincial and municipal governments (Feijoó and Nari 1994).

Specific feminist issues addressed within the first decade of the return to democracy included promoting reproductive rights and programs to support working mothers, and eliminating violence against women. Argentina pledged to continue to improve the status of women by signing and ratifying CEDAW. Abortion remains illegal (with a few exceptions) in Argentina, but it is no longer a taboo subject (Htun and Piscopo 2010; Feijoó and Nari 1994). Domestic violence gained recognition as a social problem, and the government took limited actions to address it as such. For instance, the government established institutions to provide health services, legal counseling, and police-training programs, along with special precincts staffed by women for women in Buenos Aires. While there is still room to improve these services, Argentina made quick progress toward developing a comprehensive collection of policies on both domestic and sexual violence, moving from no measures to deal with violence against women in 1975 or 1985, to a score of seven on Htun and Weldon's ten-point scale ${ }^{1}$ evaluating such policies in 1995 and a score of eight in 2005 (Htun and Piscopo 2010).

In terms of representation in the legislative branch of formal politics, the number of women elected to the lower house of Argentina's bicameral congress, the Chamber of Deputies, declined during the transition period from 1983 until 1991 (Feijoó and Nari 1994). However, women effectively mobilized to affect legal change to rectify the problem. Argentina's electoral

\footnotetext{
${ }^{1} \mathrm{Htun}$ and Weldon developed a ten-point scale to evaluate and compare policy on violence against women. A country that has a comprehensive array of policies on domestic and sexual violence - including shelters, rape crisis centers, and other facilities; public awareness campaigns; training programs for judges, police and other law enforcement personnel - receives a score of ten. A score of zero indicates no policy activity (Htun and Piscopo 2010, 9).
} 
system influenced how women were able to act toward this change. Argentina has a closed-list, proportional-representation electoral system. The bicameral Congreso Nacional (National Congress) is composed of the 257-member Cámara de Diputados (Chamber of Deputies) and the 72-member Senado (Senate). Deputies are elected to four-year terms in twenty-four multimember electoral districts, which elect two to thirty-five deputies depending on the size of the population. There is a 3 percent threshold for parties to win a seat. Three senators are elected from each district. The party or coalition that wins the most votes receives two seats and the runner-up receives one seat (IPU 2013).

Female activists in Argentina did not feel that their demands were being met by the government, and they believed that more access to government positions would have a positive effect on the success of achieving their goals. Dissatisfied with the slow 'instrumental track' to gender parity in government, they rejected that model of gradual improvement, based on the assumption that increased resources would result in gender equality. They could see that the core of the problem was the exclusion of and discrimination against women (Dahlerup 2006).

A female senator from the Unión Cívica Radical (Radical Civic Union, UCR) political party introduced a quota bill in 1989, and a multiparty group of women deputies introduced a bill in the lower house. Feminists in fifteen different parties organized and lobbied for support of the bills, and they filled the congressional galleries to cheer for the legislators who supported the bill (Franceschet and Piscopo 2012). They presented both justice and utility arguments to support the quota legislation, and chose to focus on what women would do to enhance politics once elected. President Carlos Menem publicized his support of the bill and helped to get it passed. In 1991 Argentina became the first country to pass national-level gender quota legislation with the November passage of the Ley de Cupos. The Argentine national quota law has been praised as 
one of the most effective quotas in the world because it is a candidate quota that includes real mechanisms for implementation and enforcement (Htun 2002; Gray 2003). In the past several decades, gender quotas have been instituted as the most effective mechanism for increasing women's access to and voice in politics in countries around the world (Dahlerup 2006; Franceschet and Piscopo 2012).

The national quota law passed in 1991 applies only to elections for the Chamber of Deputies and requires that women must constitute at least 30 percent of each party's candidate list. Not only that, but it mandates that women's names be placed in electable positions and that any party lists that fail to comply with the national quota law must be thrown out (Franceschet and Piscopo 2012). The first election held after the quota was put into place occurred in 1993 and resulted in women's share of the Chamber increasing from 5 percent to 14 percent.

Although the quota system increased the number of women in office, it confronted problems with its enforcement. Gray identified two major enforcement issues: first, only the female candidate herself who was directly affected by the violation of the law could contest a noncompliant party list; and second, many federal prosecutors and judges were hostile toward the law (2003). The first problem was resolved by the extension of the right to contest a party list to any affiliate of that party in the district and the National Women's Council (Gray 2003). The Attorney General addressed the second issue by ordering federal prosecutors to ensure full compliance with the law (Gray 2003). With those issues resolved by 1995, the other half of the Chamber went through its first election cycle with the law in place, and women's share of the Chamber rose to 27 percent (Franceschet and Piscopo 2012). In many countries, gender quotas are treated more as ceilings rather than minimal limits for the number of women candidates, but this has not been the case in Argentina (Dahlerup 2006). By 2007, women held 38 percent of the 
seats in the Chamber of Deputies, and that level of female representation has remained consistent (Franceschet and Piscopo 2012; IPU 2013).

Importantly, the national quota law was also in effect for the 1994 election of delegates to the Argentine Constituent Assembly, and women comprised 26.2 percent of the resulting body (Gray 2003). Women's presence in the Constituent Assembly ensured that women's interests were heard in the crafting of the new constitution. The women helped to achieve reforms to promote the status of women, including policies to empower women in political participation. The constitution itself now explicitly supports the principle of affirmative action for elected offices in the form of gender quotas (Gray 2003).

A reform of electoral rules extended the application of the national quota law to the Senate, beginning with the 2001 elections. That year, women's representation in the senate increased dramatically from only 6 percent to 38 percent (Fraceschet and Piscopo 2012). As of February 21, 2013, women held 39 percent of the Argentine Senate seats (IPU 2013). Although there is a greater percentage of women in the Congress than the percentage of women candidates required by the quota law, never has women's presence on candidate lists exceeded the threshold of the quota (Htun and Piscopo 2010). The success of the Argentine national quota law at increasing women's representation to approximately 40 percent of both houses of the Congress can be attributed to specific aspects of the law and the design of the Argentine electoral system (Matland 2006). Richard Matland points to three necessary and sufficient conditions for such candidate quotas to be effective: a proportional representation system, an electoral system that produces high party magnitude, and good faith or forced compliance by the political parties (2006, 290). All of these requirements are present in the Argentine system. 
This is the context for women in Argentine politics today. They have achieved high levels of female representation in the national legislature and Argentina is currently ranked $18^{\text {th }}$ in the world in terms of women's legislative representation (IPU 2013). Considering that women have managed to secure access to formal politics through the national legislature, how have they used these new positions to promote women's interests, and how has this new dynamic altered the way in which Argentines perceive women in such stations of political leadership? I will address these questions in the final section of this paper.

\section{Chile}

The political history of Chile is quite different from the unstable past of its neighbor. Until the 1973 military coup that established the Chilean dictatorship, Chile had been one of the most stable constitutional democracies in Latin America. Not only that, it had boasted one of the highest percentages of women in the national legislature for countries in its region (Gray 2003). In 1971, Chileans elected Salvador Allende, a Socialist, to the presidency. He implemented an economic plan that included the nationalization of banks and large private businesses, and under his rule the country enjoyed a brief period of well-being until the end of 1972 when inflation began to skyrocket. Although socialist governments generally place a high value on gender equality, at least rhetorically, Allende failed to make any meaningful strides in that direction during his short-lived tenure as the head of the Chilean government (Huneeus 2007; Franceschet 2005). This left women, particularly those from the middle and upper classes who had suffered from his policies, available for mobilization in the conservative movement against him. Tensions rose and were made visible in public demonstrations and strikes. On September 11, 1973, Augusto Pinochet led the military in an assault on the presidential palace (el Palacio de la Moneda) and installed himself as the head of a new military junta government (Huneeus 2007). 
Just as the Argentine military dictatorship had implemented a policy of state terrorism, so did Pinochet in Chile. Under his leadership, the state immediately repressed the population by terrorizing them and immobilizing political organization (Hensman 1996). The military arrested, tortured, and killed thousands of people in its efforts to instill order and stomp out communism. Similar to the military dictatorship of Argentina, Chile's authoritarian military government promoted the traditional aspects of gender ideology associated with marianismo, and manipulated that ideology in a doctrine of national security that emphasized women as the moral strength of the country. The regime discursively linked familia y patria (family and fatherland) through women's roles as the reproducers of Chilean values and tradition (Francescheet 2005, 25). The regime also valorized women for their 'apolitical nature' in a time when Pinochet banned political organization and identified politics as the cause of the crisis that he claimed he had intervened to resolve (Franceschet 2005).

The Chilean dictatorship also imposed a harsh "shock therapy" of radical transformation of the economy to a market-based system. Similar to the neoliberal experience of the Argentine dictatorship, Chileans suffered under the severe effects of these policies. Resulting problems included rises in unemployment and the cost of living, a lack of access to essential services when the state privatized services such as healthcare and education (Franceschet 2005). Women across classes were united in their common experiences in coping with the contradictions between the dictatorship's gender ideology that valued the mother and its policies that violated the principles of family through its repressive actions. Women joined together to organize on behalf of human rights, taking their 'private' concerns public, and to provide for their families in spite of the economic hardships they faced. Chilean women pushed beyond organizing in these more conventionally feminine ways, which could be interpreted as an extension of their private 
concerns into the public sphere, to rethink what democracy meant for women specifically. They explicitly pushed not only for a return to democracy, but for the establishment of a democracy that included meaningful citizenship for women (Caivano and Hardwick 2008; Franceschet 2005, 27). The movement was characterized by use of the popular slogans ;Democracia en el país y en la casa! (Democracy in the country and in the home!) and ;Si la mujer no está, la democracia no $v a$ ! (If women aren't there, democracy won't go anywhere!) to mobilize women for a full democratic transformation in Chile (Franceschet 2005, 27).

Chilean women did not start out organizing with such an explicit opposition to the regime, however. They began with efforts to take care of their families by consolidating their resources in ollas comunes (community kitchens) where each person contributed to buying, preparing, and serving the food (Hensman 1996). The strict military regime perceived any assemblies outside of its control - even women's community kitchens - as subversive. The military raided the kitchens and arrested the women involved, forcing the groups to become clandestine and causing them to organize against the government. As these women joined together to solve their economic problems, they began to realize that they as women faced similar challenges within the context of their own homes and families. It was in that context that women began to recognize their status in the home as akin to the status of the people under authoritarian political rule. This realization inspired them to make such feminist demands as those embodied by the slogans listed above (Franceschet 2005; Hensman 1996). Women of the working and middle classes alike started to fight for a cultural transformation to eliminate machismo sexism and its manifestations in gender violence, discrimination at work and home, household responsibilities, and reproductive rights (Hensman 1996, 51). 
Women, initially because of their roles as mothers, were the members of society who first stepped out in public to oppose the regime. Demobilization eliminated the labor movement as an effective political group. The regime forced political parties underground, severing from civil society. Until 1986 political parties contributed nothing to the opposition to the military regime (Franceschet 2005). Given the increasing weakness of the regime, under pressure from the United States and UN sanctions, by 1983 the parties had begun to join the opposition, which had been primarily composed of women's organizations and human-rights movements. Together, they increasingly organized opposition and further delegitimized and destabilized the Pinochet regime. A provision in the military's 1980 constitution stipulated as a requirement a plebiscite to determine whether Pinochet's rule would continue for another eight years. Pro-democratic groups pressured the government to ensure that the 1988 plebiscite was free and fair. The opposition narrowly won the vote, and the transition to democracy became reality. The government scheduled elections for a president and congress for 1989. Meanwhile the outgoing military regime worked with the opposition groups to negotiate the details of the democratization process, including some reforms to the constitution (Franceschet 2005).

The military's influence on the institutional framework for the new government, through the continuation of its 1980 constitution and its active participation in negotiation of the transition of authority, has had significant implications for democracy in Chile (Gray 2003). The constitution failed to establish full civilian control over the military (which was granted budget and veto power), ensured that the executive remains far stronger than the parliament, and established a binomial majoritarian electoral system that favors the parties of the right (Franceschet 2005; Gray 2003). The military's continued hold on power also contributed to the failure to address the human rights violations committed in the name of the state during the 
dictatorship (Franceschet 2005). An amnesty law passed in 1978 prevented the prosecution of most military officials who committed the atrocities. In fact, many of the people who committed human-rights violations remained in positions of power for years, and in some cases decades, after the 1990 return to democracy. Pinochet himself continued to serve as the Commander in Chief of the Army assumed a seat as a senator-for-life (Franceschet 2005; Skármeta 2012).

In the binomial majoritarian system, all seats are elected from two-member districts in which each party or coalition competes with an open list of two candidates. Citizens vote for one candidate, and the first seat goes to the candidate with the most votes from the list that received a simple majority of the citizen votes. If one half of the total votes received by that list is higher than the total vote of any other list, the second candidate from the majority list gets the second seat. If that number is not higher than the total votes of any other list, then the candidate with the most votes from the second most popular list wins the second seat. In simpler terms, a party must win 67 percent of the votes to win both seats, but a party in second place would only need 33 percent of the votes to win the second seat (50 percent of the district's representation).

This electoral system shapes the political landscape of Chile in three ways that stand out. First, it pushes parties to organize into two major coalitions in order to be competitive in elections. Even though Chile technically has a multi-party system, small, independent parties cannot hope to win any seats through this electoral system. Second, it over represents the areas that supported Pinochet in the 1988 plebiscite through biased district lines, or gerrymandering. Third, it heavily favors the coalition of the right, the Coalición por el Cambio (Coalition for Change, CC), formerly known as the Unión por Progreso (Union for Progress, UPP). The right has historically won one third of the vote, which is all that is necessary to win half of the 
contested seats (Franceschet 2005; Gray 2003). Despite the left's repeated efforts to reform the electoral system, the binomial majoritarian system remains in place.

The original design of the bicameral Congreso Nacional (National Congress) featured a Chamber of Deputies filled by 120 elected members and a 48-member Senate in which 38 seats were filled by free elections, two by vitalicios (senators for life), and 8 by designados (nonelected senators). From the beginning of the term of the first freely elected post-dictatorship president, parties on the left started trying to eliminate the authoritarian features that remained in Chile's political structure. However, not until late 2005 did the Congress pass reforms to eliminate all of the nonelected senators, leaving the Senate with a total of 38 members. Senators continue to serve 8-year terms while the deputies serve 4-year terms.

The issues listed above remain the chief broad, structural problems that the authoritarian government created before its departure. Chilean women, however, have faced additional challenges in making sure that their interests are addressed in the new democratic system. First, women have had to contend with the fact that political parties remain the dominant forces in Chilean politics. Political parties had been significant forces within Chilean societies until Pinochet forced them underground as a part of the regime's efforts to eliminate formal politics. Indeed, this move blurred the traditional dichotomy between formal and informal politics (Franceschet 2005). It was in that context that women's activism in informal politics (i.e. community organizations) emerged as effective and valued. In fact, their informal activities became the center of opposition politics. With the return to party politics in the late 1980s, however, women and their activism have once again been depoliticized; their community actions are again considered a simple extension of their roles as mothers who simply seek to nurture their families and the community (Franceschet 2005). 
Chilean women were not satisfied with the depoliticization of their activities. During the dictatorship, they had criticized the way that the political process had marginalized women's gender-based concerns, and they were not willing to return to a form of politics that they understood to be an incomplete democracy because it excluded 50 percent of the population (Franceschet 2005). During the early 1980s, Chilean women formed several feminist organizations. One of the most notable groups, Mujeres por la Vida (Women for Life), coalesced as a response to human-rights violations. Its members, however, were not necessarily relatives of victims, but women already engaged in political activities. These women had been active in a variety of political parties and they decided to work together to find a way to unite the fragmented opposition into one force that could achieve the goal of democracy. They held a women-only event that drew 10,000 women together in opposition to the dictatorship, and Women for Life emerged from this event as a group dedicated to women's unique way of practicing politics that rose above partisan squabbles (Franceschet 2005). In 1986 at an opposition event called the Asamblea de la Civilidad (Civil Assembly), Women for Life presented a statement of demands that was incorporated into the Pliego de Chile (Chilean People's Charter). They avowed that true democracy necessarily includes women. Their demands included respect for human-rights; access to education, healthcare, and housing; the creation of dignified jobs; and an end to unemployment. Some of their demands were even more explicitly feminist: free contraception on demand, divorce legislation, equality within the family, and state promotion of women's participation in political organizations (Franceschet 2005, 72).

In 1988, as the plebiscite on Pinochet's rule was approaching, another feminist organization called the Movimiento Feminista (Feminist Movement, MF) built upon the demands of the Women for Life and published "Women's Demands of Democracy" to call on 
Chilean women to voice their interests in political parties, social organizations, and religious institutions (among myriad other organizations) and to demand a commitment to inclusion of women in the new democratic system. They called for specific policy actions, including the formation of a state agency to create policy to benefit women and to protect women's participation in all sectors of national life, and the establishment of gender quotas for government and parliament. The women stated an appreciation for their roles as mothers, but insisted that they as individuals are more than just mothers, and that women should have the choice to forego motherhood if they choose to do so. Issues such as quota legislation and reproductive rights were dropped from the transition agenda because they were seen as too radical, but the MF request for a state agency for women was fulfilled with the establishment of the cabinet-level ministry called the Servicio Nacional de la Mujer (National Women's Service, SERNAM) in 1991 (Franceschet 2005, 73).

The exclusion of "radical" feminist issues from the transition agenda was due, in part, to differences within the women's movement. During the early years of the dictatorship, women were forced to organize independently because the regime prohibited traditional political organizations such as parties. As they worked together, women developed a sense of gender solidarity, and their autonomy became an intentional strategic decision to stay above the masculine practice of politics that they viewed as corrupt (Franceschet 2005, 42). That early autonomy fostered the growth of the women's movement and a gender critique of politics that made women's interests visible. As political parties began to resurface, however, women faced a difficult choice: remain autonomous and risk marginalization from the transition process and the resulting institutions; or opt for the practice of double militancy and join the political parties. Double militancy is a strategy that involves efforts to exert greater influence by bringing feminist 
agendas into political parties, the state, and other official political organizations (Alvarez 2009; Franceschet 2005). However, women with feminist visions had to give up on some demands in order to work with the men in political parties.

The autonomy versus double militancy debate created significant divisions that weakened many women's organizations in Chile, and many other countries. Many leading feminists opted for double militancy and joined political parties. This choice was successful in that it gave feminists the opportunity to incorporate their gender-based demands on the agenda for the transition to democracy. As the parties began to rebuild, they needed the connections that the women's movement had developed with civil society in order to generate support, and this allowed women to enter the parties in a position of relative strength. However, as previously mentioned, double militancy also subjected the feminist agendas to party supervision. Political parties viewed women's interests, such as gender quotas and reproductive rights, as insignificant or too radical - perhaps they saw them as too feminist for a machista culture or as an invitation for disapproval from the Catholic Church - and those issues were left off of the agenda (Franceschet 2005). Feminists who chose autonomy as the best way to achieve their goals saw the women who dropped certain demands to participate in political parties as sell-outs, contributing to severe divisions between women.

The resurgence of political parties led to the fragmentation of feminist and women's organizations over not only debates of autonomy versus double militancy, but also ideological differences. Class identity had been the major determinant of Chilean political-party affiliation and organization before the dictatorship, and these were among the growing divides that emerged as Chile progressed toward and entered the redemocratization process. The political parties recognized the social power of the women's organizations and actively sought to direct their 
mobilizing power for partisan ends. Women of the lower or working classes were more likely to request certain state policy actions to support women and less likely to demand their own roles in the political system. They continued to organize in informal politics, which has few linkages to the formal political arena of the state, making it more difficult to voice their concerns. Middleand upper-class women, on the other hand, were more likely to join the political-power structures and advocate for their interests in the reemerging democratic system of formal politics (Alvarez 2009; Franceschet 2005).

As the political parties of the opposition began to prepare their candidate lists and develop their platforms, women lamented their exclusion from the process. Parties nominated few women as candidates and it appeared that the traditional manner of politics was reasserting itself. As the opposition organized itself into a center-left coalition of parties known as the Concertación de los Partidos por la Democracia (Coalition of Parties for Democracy, CPD), women of the opposition parties joined with feminists and with women from NGOs to create the Concertación Nacional de las Mujeres por la Democracia (National Coalition of Women for Democracy, CNMD). CNMD was explicitly not a feminine arm of the CPD, but instead its own organization whose purpose was to support women candidates and to prepare a government program for women. Some of these women leaders had key access to the party elites and were able to place some of their issues on the CPD agenda. The CPD presidential candidate adopted the slogan "democracy in the country and in the home" during his campaign, but he ignored women's issues that challenged the interests of the Catholic Church (Franceschet 2005, 79).

Much like what has occurred in Argentina, women in Chile have had far more success addressing practical 'feminine' issues (such as health and violence against women) than incorporating more feminist strategic objectives like reproductive rights. That does not mean, 
however, that Chilean women have given up on their feminist concerns. Although reproductive rights were excluded from the transition process, Chilean feminists have made efforts to address these issues again, with limited success. The government finally legalized divorce in 2004 , and even then the active opposition of the Church made it difficult to pass, despite overwhelming public support (BBC News 2004). Abortion remains illegal in Chile under all circumstances; but Michele Bachelet (Chile's first woman president, 2006-2010, and current presidential candidate) expanded women's access to contraception (Htun and Piscopo 2010; Skármeta 2013). She also proposed gender quota legislation, which failed to pass, and supported programs to support working mothers.

Chile has also committed to work toward improving the status of women by signing and ratifying CEDAW, and has improved laws to counteract violence against women. On the Htun and Weldon ten-point scale measuring policies on violence against women, Chile quickly progressed from a zero (no measures) in 1985 to a six in 1995, and a seven in 2005 (Htun and Piscopo 2010). Chile has moved toward even more comprehensive laws in this department. Current Chilean president Sebastián Piñera, of the CC, helped to pass and enact a femicide law in 2010 and launched national media campaigns against gender violence (Kim 2013). Chile's femicide law increased the penalties for femicide, defined as the murder of a woman by a current or past romantic partner, and enhanced legal protections for abused women who kill in defense of self or family. The government touts the 30.6 percent decline in femicides between 2010 and 2012 as a sign of success. The Piñera administration has committed to furthering the protection of women by increasing its budget by 21 percent since he entered office in 2010 (Kim 2013). In terms of representation in the legislative branch of formal politics, Chile has not even come close to achieving the levels of gender parity experienced by its neighbor Argentina. In 
2013 women occupy only 14.2 percent of the seats in the Chamber of Deputies and only 13.2 percent of the Senate seats. Among other factors, this could be attributed to the absence of national quota laws in Chile (Edwards 2013; IPU 2012). The Chilean Congress does not seem to be open to gender quota legislation, but President Piñera and Carolina Schmidt, the Minister of SERNAM, have just announced an innovative new plan to incentivize women's participation in political campaigns. The new project establishes incentives for political parties that nominate women as a certain percentage of their candidates and for the women candidates themselves. For parties that meet the quota, each vote a female candidate receives will be rewarded with a certain amount of money; the party will receive 30 percent of that money while the candidate will receive 70 percent. If the candidate wins, the party will receive an additional set sum. The government indicated that these reimbursements would represent about a 50 percent increase to the existing financing and will be only a temporary measure in place until women fill at least 30 percent of elected seats (SERNAM 2013).

The three major parties of the CPD - the Partido Demócrata Cristiano (Christian Democratic Party, PDC), the Partido por la Democracia (Party for Democracy, PPD), and the Partido Socialista (Socialist Party, PS) - are the only Chilean political parties with seats in Congress that have adopted voluntary candidate quotas (Gray 2003; Franceschet 2005; IPU 2013). However, some quotas only apply to internal party elections or are not used for national elections, and weak enforcement is often a problem.

Although the party quotas have not had much effect on increasing the number of women in Congress, they have had some success at increasing women's representation in party leadership positions (Gray 2003). This could actually be an important indication of progress because the parties are the gatekeepers of access to formal politics in Chile and it is the party 
elite who set the political agenda (Htun and Piscopo 2010). Greater women's access to party leadership could allow them to have more influence in the issues that the parties plan to address and it could also give them the opportunity to restructure party functions to make it possible for more women to participate (IDEA 2010). For example, they could change the meeting times so that working women with families would be more able to attend, or they could encourage 'feminine' styles of leadership that have previously been dismissed as weak (Franceschet 2005; Htun and Piscopo 2010; Pereda Pérez 2011).

This is the modern context for women in Chilean politics. The percentage of women in Congress is increasing only incrementally with each election cycle and Chile is currently $92^{\text {nd }}$ in the world in terms of women's legislative representation (IPU 2013). However, women have been gaining more than 20 percent of leadership positions in certain left-leaning parties, and Chile has elected a woman president. Considering that women have managed to secure some access to formal politics, how have they used these new positions in relation to women's interests, and how has this new dynamic altered the way that Chileans perceive women in such stations of political leadership? These are the primary questions that will be addressed in the final section of this paper.

\section{Roles and Perceptions of Women in Political Leadership}

\section{Current Obstacles to Reaching Office}

Current obstacles to women's access to political leadership are common across both Argentina and Chile. Many of these barriers are the result of the persistence of machismo in the social and political cultures of these Southern Cone countries. Primary barriers include socioeconomic factors and the roles of political parties and electoral systems (Htun 2002). 
The historical relegation of women to the private sphere as a result of machista attitudes has contributed to the 'feminization' of poverty: women make up a disproportionate percentage of the world's population living in poverty. This socioeconomic deprivation puts women at a disadvantage for gaining access to political institutions. If a woman would like to run for office, she must find a way to finance an expensive campaign (Htun 2002; Franceschet 2005). Political parties are often reluctant to pay for women's campaigns if they feel that a male candidate would have a better chance to win. Running for office or receiving a nomination to fill a ministerial post also requires connections that are traditionally fostered through participation in the work force (Htun 2002). No more than 40 percent of Chilean women participate in the labor force, while as much as 60 percent of Argentine women are active in the labor force (Seager 2009). These numbers indicate that only a limited percentage of women in the Southern Cone have independent access to resources for their individual use in, for example, political campaigns.

Although the overall level of development in a country is not in any way a reliable indicator of women's representation in that country, advances in women's economic situations can put them in a better place to gain access to power (Jaquette 1997; Htun 2002). Women and men politicians alike tend to be a part of the more elite classes of society and are generally more educated than the general population, so improving women's economic situation can augment her chances of gaining access to public office (Franceschet and Piscopo 2010).

In both Argentina and Chile political parties are the structures that individuals must use to gain access to political office. Men continue to rule political parties and administer them in traditional masculine ways, developed while men were the only gender group allowed to access formal political positions (Dahlerup 2006; Franceschet 2005). The male leaders of political parties have doubted women's abilities to lead or to win elections, and therefore have relegated 
them to only minor roles during the first stages of transition to democracy in each country. The disproportionately male party leaders also determine the party agendas and wield the power to either exclude women's issues from the agenda or to punish women members of parliament who may break the party line on gender-based issues (Htun 2002). Furthermore, political party meetings are often held at night, at times when many women are unable or unwilling to attend because of familial responsibilities. In these countries, the male-dominated party rules have resulted in the exclusion of women from politics (Franceschet 2005; Pereda Pérez 2011).

\section{Public Attitudes about Women's Leadership}

Recent surveys have clearly demonstrated that the Latin American population supports women in power. A 2000 poll conducted in major Latin American cities found that 57 percent of respondents believe that a greater presence of women in political office would lead to better government. More than 90 percent said they would be willing to vote for a woman president (Htun 2002). This is not surprising given that many countries across the region, including both Chile and Argentina, have already elected women presidents. A noteworthy trend among recent elections of presidentas in Latin America is that, while some of these women have family ties to men in the political elite, the women themselves have had successful careers in politics based on their independent merits. Previously, throughout Latin America, women serving as heads of government have generally reached that office because they were the daughter or wife of a man who had filled that role (Dahlerup 2006; Htun and Piscopo 2010).

Latinobarómetro polls conducted in Argentina and Chile have also shown that the populations of these countries believe in women's capacity to be political leaders. A 2009 survey found that 77 percent of Chileans disagreed with the statement "Men are better political leaders than women". The same survey showed that more than 72 percent of Argentines also disagree 
with that statement. A 2006 survey conducted in Chile that asked respondents to "choose the main reasons why you think there are not enough women in public charges, or do you think there are women in public charges," resulted in varied answers. Results showed that 9.3 percent of respondents believed women did not have time for politics. Slightly more than 47 percent of respondents answered that "There are women in public positions", while only 5 percent indicated a belief that women are either not prepared for politics or that politics is not a woman's place. Nearly 40 percent of respondents answered that there were not enough women in public charges because of discrimination: 18 percent said that "men do not leave place" while 19.5 percent responded that "the political system discriminates against women." When the survey was administered in Argentina, 6.1 percent of respondents said that women have no time for politics; 41.5 percent believe that there are enough women in public positions; a total of 5.5 percent said that women are either not prepared or that politics is not their place; and a total of 46.9 percent of respondents said that low numbers of women in public charges is the result of some form of discrimination (Latinobarómetro Corporation 2013).

While the Latinobarómetro polls asked a wide variety of questions on different issues related to women's rights and democracy, it lacks background information to explain the results of the survey. In Argentina, where far more women fill legislative offices than in Chile, only 41.5 percent believe that there are enough women in public charges compared to 47.3 percent in Chile. This might be attributable to the fact that Chile had a woman president at the time in Michelle Bachelet, who had committed to having an equal number of men and women in her cabinet, while Cristina Fernandez de Kirchner had not yet been elected president of Argentina (Htun and Piscopo 2010). There was also a difference of 7 percent between the Argentines and the Chileans who believed institutional or men's discrimination kept women from office. The 
greater perceptions of discrimination among Argentines could be the product of higher levels of awareness of gender discrimination in politics as a result of the publicity of the quota laws. The difference could also be attributed to the fact that compared to Argentina, political rhetoric in Chile is not as progressive on gender rights issues and the term 'feminism' is still rejected (Franceschet 2005; Feijoó and Nari 1994).

Women's organizations in both Argentina and Chile implemented a politics of difference, emphasizing the value of women's experiences and leadership styles, to promote their inclusion in formal politics. Notably, Latin Americans indicate that they vote for women precisely because they believe in the politics of difference and feel that women's positive characteristics (aligned with the marianismo gender ideal) make them uniquely capable of governing well (Htun 2002; Franceschet 2005; Pereda Pérez 2011). A poll conducted across Latin America showed that Latin Americans feel that women outperform men in the following areas: honesty (66 percent), reducing poverty (62 percent), managing the economy (59 percent), and combatting corruption (57 percent). Most of the public did not believe that women would perform better than men on defending public security or running the army (Htun 2002). The Latin American public has actually pushed for women to fill political positions because they see them as "pure" and defenders of the family, and therefore believe that women will be less corrupt than male leaders. The public is disillusioned with the quick return to political corruption within democracy and is eager for a new form of politics, which women might be able to provide. Women continue to see themselves in that way and are more likely to mobilize based on their roles as mothers in defense of family interests as opposed to self-interest (Htun and Piscopo 2010; Jaquette 1997). In fact, studies across regions have concluded that women are less corruptible (Rivas 2008; Swamy et al. 1999). 
The survey results outlined above show that the attitudes of the general population are not a real obstacle to women gaining political office. This would suggest, then, that the true barriers to women's access to political positions reside within party and institutional structures (Htun 2002). Therefore, the task of increasing women's representation in politics may be far less daunting than it appears. Argentina and Chile were able to resurrect democratic institutions after years of dictatorial rule; if those institutions were redeveloped within a matter of years (or less), it should be feasible to readjust those arrangements and structures to grant women greater access to political offices (Franceschet 2005; Htun 2002; Htun and Piscopo 2010). Institutional reform is a more concrete target to work toward than a major adjustment of the public's beliefs about women in political leadership (Gray 2003). Public attitudes could also be a motivating factor that supports institutional reform. Overall, party affiliation in Latin America is low. Some parties have begun to recognize that they are alienating large portions of society and have made at least minimal moves toward reform to open opportunities for women to rise to leadership (Htun 2002).

\section{Women's Roles in Formal Politics}

Women have made the most progress in gaining access to legislative positions. This can be attributed to the quota laws (in Argentina) and the different mechanisms for filling government positions. First, there are more members of Congress than there are executive branch positions, such as head of government or ministry directors, in both Argentina and Chile. This decreases the overall level of competition for these offices. Second, the methods for electing legislators are more open and inclusive. Argentina uses a system of closed-list proportionalrepresentation to elect legislators, which has been shown to present greater opportunities for women to gain office than plurality/majority electoral systems. Chile's binomial majoritarian electoral system is a strange hybrid of proportional-representation and majority systems since 
each district only elects two candidates, which also disadvantages women who seek to gain political office. However, elected executive positions such as the presidency are filled through a plurality/majority electoral system. Political parties generally tend to favor men candidates for these positions because they believe that men will receive more votes than women, which makes it far more difficult for women to access these offices. Ministry positions can be easier or harder for women to access, depending on the president, because they are filled by appointment rather than election (Htun 2002; Htun and Piscopo 2010).

\section{The Legislative Branch}

Within the legislature, women tend to be disproportionately concentrated in the "soft" committees, perceived by insiders to be more "feminine" (Htun and Piscopo 2010). The "soft" portfolios, reflective of conventional feminine interests associated with the ideal of womanhood prescribed by marianismo, include such areas as social services, education, culture, housing, the family, and healthcare. This holds true throughout the region of Latin America, including in Argentina and Chile. From a gendered perspective, this can be interpreted in two ways: the male political elites who determine committee assignments discriminate against women to avoid placing them in the traditional "powerful" and prestigious committees; or women themselves choose to work in these areas because they coincide with their gender interests.

Both are true. Some women have been steered into the soft committees despite expertise in other areas, resulting in the virtual exclusion of women from powerful committees. However, women are more likely request an assignment to committees such as justice and education more often than on budget and finance. Some women also enter politics with a specialization in social policy or gender policy and ask to be placed on committees that deal with those issues.

Placement in the "soft" committees also gives women greater opportunities to influence policies that have a significant gender impact and can put women in a more powerful position to 
introduce and pass legislation to improve women's status. In fact, the presence of women on these committees, coupled with an increasing focus on social issues in the Southern Cone (especially Chile), has helped to galvanize progress on these issues and augment their public importance. Nevertheless, the overconcentration of women in social-issue committees reflects a continued gender bias and hinders the incorporation of women's voices in major topics that shape women's lives, such as economic policy or foreign affairs (Htun and Piscopo 2010; Jaquette 1997).

Evidence shows that while party identity is a better indicator of legislative preferences than gender, women are more likely than their male colleagues to introduce and vote for bills on women's issues (Franceschet and Piscopo 2012; Gray 2003; Htun and Piscopo 2010). When women do propose and support policies on gender issues, they tend to address 'practical' or 'feminine' issues such as violence against women, education, or basic gender equity rather than the more strategic feminist objectives such as reproductive rights (Gray 2003; Franceschet 2005).

Ideological differences among women are even more exaggerated today than at the time of transition to democracy in each country and continue to cause divisions within women's movements and between women in Congress, even on issues that pertain to women. Some women explicitly reject the feminist label and avoid gender issues altogether. Meanwhile, conflicts arise between conservative women, who tend to advocate for women within the framework of marianismo, and the women of the ideological left who are more interested in promoting a feminist agenda (Gray 2003; Franceschet 2005; Htun and Piscopo 2010; Starr 2006). These divisions and partisan politics hinder women's ability to form cross-party coalitions to advocate effectively for policies that improve the status of women. Furthermore, when women do work to promote women's gender interests, they are often unable to garner the male support 
needed to pass legislation or approve budgets (Htun and Piscopo 2010). For example, bills related to women's rights are more than twice as likely to fail as other types of bills (Htun and Piscopo 2010).

Women confront one other limitation regarding their roles in Congress: very few women gain positions of leadership within Congress. Women have less access to party leadership positions that shape the agenda that the party will support and choose the chairs of congressional committees. Since women are not in these positions themselves, they have to get the support of male party leaders and committee chairs in order to even have their bills make it to the floor for debate (Htun and Piscopo 2010).

The Executive Branch

As previously mentioned, both the mode of electing candidates to executive office and filling ministerial positions by presidential appointment tend to disadvantage women (Htun and Piscopo 2010). Impressively, both Argentina and Chile have been governed by their first freely elected women presidents in the first decades of the twenty-first century. Argentine citizens elected Cristina Fernández de Kirchner in 2007 and again in 2011. Although her husband, Néstor Kirchner, served as president before her, Cristina (as she is known to the public) had already worked more than 20 years as a successful politician in her own right. The Argentine Constitution currently prohibits an individual from serving more than two terms as president, but Cristina is pushing for a reform to allow her to run again in 2015. In Chile, Michele Bachelet served as president from 2006 until 2010. A president cannot serve consecutive terms in Chile, but Bachelet enjoyed an approval rating of 83 percent when she left office in 2010 and has recently announced her candidature for the office in the elections to take place next year (Reel 2007; Comando Michelle Bachelet 2013). 
These two women, who have reached the highest level of political office in their respective countries, offer an interesting contrast in leadership styles, particularly as it relates to gender issues. Kirchner has appointed only three women to direct ministries in her administration. That means that only 13.6 percent of Argentina's current ministers are women (Gobierno de la República Argentina 2011). On the other hand, Bachelet had pledged to promote gender parity within her cabinet while she was still on the campaign trail, and she lived up to that promise. She herself had served in the cabinet and had never participated in an election until running for president (Htun and Piscopo 2010). The current administration in Chile has a cabinet that is 27.3 percent women, an amount that is still above the regional average (Gobierno de Chile 2013; Htun and Piscopo 2010). Throughout Latin America, there is a trend of women gaining greater shares of cabinet positions (Htun and Piscopo 2010).

However, just as women in the legislature are generally relegated to "soft" areas of governance, so are women in the cabinet, although recent appointments of women to cabinet positions might indicate that the trend is changing (Htun and Piscopo 2010). Bachelet served as both Minister of Health and Minister of Defense before becoming president, and she placed the female ministers in her cabinet in some of the more traditionally powerful positions, including Defense Minister, Chief of Staff, Economy Minister, and Planning Minister (Carmona 2006; Comando Michelle Bachelet 2013; Gallardo 2006). One of the current female ministers in Argentina serves as the Minister of Security (Gobierno de la República Argentina 2011). However, the other two women in the Argentine cabinet are the heads of social divisions, and all of the women in the current Chilean cabinet serve in "soft" positions. Clearly, the influence of a traditional view of gender continues to limit the roles available to women in politics. 


\section{Perceptions of Women in Formal Politics}

Argentine and Chilean women have become increasingly visible in their national political institutions and have gained the attention of the rest of the world (Barrionuevo 2007). Argentine and Chilean women organized and fought for equal access to politics in order to have their voices heard and to have a say in the decision-making processes that affect their daily lives. Some rallied around feminist demands to change the sociocultural conditions that repressed women in public and in the home. Women directly and indirectly challenged the traditional perception that women did not belong in politics because they were too pure and weak, too uneducated and passive. As a result of their efforts, women have gained access to formal political positions. So how have women's presence and actions in politics affected conventional perceptions of women in the Southern Cone? While some female politicians have brought attention to the inferior status of women and have made some progress toward creating states that foster gender equality, their presence has not significantly altered conventional perceptions of women; it has, however, redefined the significance of those perceptions.

As the previous sections illustrate, women activists in Argentina and Chile point to a politics of difference to insist on the expansion and consolidation of democracy through the inclusion of women in political processes. Statistics featured in the section "Public Attitudes about Women's Leadership" show that the Argentine and Chilean public have, overall, accepted those arguments and now look to women to change politics in a way that will minimize corruption and better represent the people (Htun and Piscopo 2010; Franceschet 2005). The acceptance of these arguments shows that women in the Southern Cone have effectively utilized the politics of difference to change the way the public views women in positions of power. They have argued that the marianismo qualities of purity, motherhood, and self-sacrifice stand out as 
reasons why women should enter politics rather than justifications for their exclusion. As a result, women in Argentina, and Chile to a lesser extent, have achieved greater access to formal politics.

However, the political elite have prevented the practice of politics from progressing at the same rate as social changes. While the culture is changing in the Southern Cone toward more acceptance of gender equality, male politicians have not proven to be measurably more willing to select women for candidacy or to promote them to leadership positions (Pereda Pérez 2011). Gender-based discrimination against women is still a major factor in political institutions and limits their capacity to effectively wield the power of their positions. The presence of women in politics has failed to increase public confidence in political institutions or the political process (Zetterberg 2009). Further research would be needed to determine if this could be attributed to women's common exclusion from the more powerful congressional committees and ministerial posts. It could be argued that the internal discrimination against women and their leadership styles within political institutions is, in itself, another form of the corruption that the public wants to eradicate from politics.

This gender discrimination could be the result of the limited understanding of political leadership among the male political elite. Leadership is conventionally associated with traditionally masculine qualities: tough talk, physical power, dominance, stoicism, and competitive rhetoric. Political men have exhibited a tendency to disregard women if they are soft-spoken, encourage cooperation or comprise, and show emotion. In other words, women are not appreciated if they are feminine. Women have attempted to make sure that their voices are heard by adopting more masculine styles of communication (i.e. speaking loudly), which has had 
some success within the political realm but has also drawn criticism from other women (Paxton and Hughes 2007; Pereda Pérez 2011; Skjelsbaek 2001)

Women's presence in political leadership does not appear to have fostered greater support for gender equality among the general public (Htun and Piscopo 2010). In some ways, it is even associated with a resurgence of sexism. Women are still viewed largely as a common feminine group rather than as individual leaders who happen to be female. The data presented above show that the public often votes for women specifically because of positive characteristics that they associate with women as leaders. If citizens vote for women because they are women, there is a risk that any controversy over how the country is being run could be attributed to a woman's gender identity as the reason for her mistakes. Such a reaction could potentially cause a backlash against women; it is not just a woman's political career at stake if she makes an unpopular decision, but also the reputations and careers of her female peers and the substantive progress made for women's interests (Dahlerup 2006; Franceschet 2005; Jaquette 1997; Pereda Pérez 2011; Reel 2007).

\section{Discussion}

There are stark contrasts between the levels of gender representation in Argentina and Chile. Military dictatorships, machismo, and powerful women's movements characterize the histories of both countries, so what factors might explain the differences in the roles and perceptions of women in formal politics in Argentina and Chile? Differences in the variation of ideology in politics, the principle values, and the ideological demographics of the populations can help to explain these differences in women's representation in the Southern Cone.

Just as it was before the military coup, Chile today has returned to a stable democracy. The binomial-majoritarian electoral system forces the development of two major moderate- 
center coalitions in the same way that the plurality, first-past-the-post electoral system fosters the two-party structure in the United States. Although significant differences exist between the CPD and the $\mathrm{CC}$, both coalitions present a moderate ideology in order to appeal to the voters in the center. Some individual parties may be somewhat more leftist or rightist than others, but the coalitions as units rest in the ideological center. The result is fierce competition for candidate selection, which historically disadvantages women. It also precludes the likelihood that a feminist party progress within the system.

Politics in Argentina, however, are prone to extreme political swings and tend to favor the leadership of exceptional caudillos, charismatic leaders who implement populist political strategies to gain access to and maintain power. Drastic fluctuations between conservative governments which promote fascist regimes to liberal socialist agendas are not out of the ordinary. This type of system allows more room for what could be considered radical feminist ideas to be heard fairly. Politics is more open to mass mobilization in Argentina, and women's experiences during the dictatorship give them an advantage in organizing today.

Chileans generally favor liberty over equality, another factor which hampers attempts to pass national quota legislation. Chile recently lifted the mandate which made voting obligatory, which indicates that the country would be less inclines to impose another type of mandate in the electoral system. Chileans against gender quotas protest that it restricts their liberty to elect whom they wish as voters. In Argentina, however, equality is a key value promoted within the political system. Kirchner pledges to create economic equality by supporting the poor through subsidies and welfare, and has made significant progress toward equal rights for gay and transgender people in Argentina, despite the firm opposition of the Catholic Church (including 
the current Pope Francis). As such, promoting gender equality through quotas for women is well within the Argentine value framework.

Women also tend to be more conservative in Chile. Despite the gender quotas adopted by parties in the more leftist coalition, the CPD, more Chilean women are elected from the conservative parties. Women also tend to vote for the right, although there are indications that this is starting to change, such as the election of the Bachelet, a socialist-atheist divorcee. Conservative Chilean women tend to enter politics from the 'mobilized mother' approach, proclaiming a need to temporarily enter politics for the wellbeing of their families and children. They support the more traditional gender roles associated with marianismo and generally do not think of themselves as politicians, and largely oppose gender quota legislation as well as other 'radical' strategic feminist objectives.

Michelle Bachelet finds success in this Chilean political system because she is a symbol of the fight for democracy; she proved her merits as a surgeon, the Minister of Health, and the Minister of Defense; she promises a leadership of cooperation and compromise; she promotes equality across party lines; and she presents herself as a new and different kind of leader. Bachelet's father was a general in the Chilean Air Force who served in a leading role under Allende. Bachelet and both of her parents were detained and tortured under Pinochet's regime, but Bachelet made her way to live in exile in Germany for a time. She is a surgeon who completed graduate studies in military science and is fluent in two languages and competent in three more (UN Women 2011b). She campaigned as a woman and made gender equality a central tenet of her platform, and fulfilled her promises to make strides for women as the president. Bachelet is a member of the Socialist Party, but she accepted some liberal economic policies to support her country's growth. In sum, she made her way to power through elite 
education, charisma, engaging with the population, and playing smart politics. She remains an exceptional figure in Chilean history, and this work illustrates that many obstacles still impede women's access to politics, but her leadership has shown that women can do the job and will open doors for women in the future.

Unlike politics in Chile, Argentina has a long history of charismatic populist leaders. Juan Perón is the supreme Argentine caudillo, but Cristina Fernández de Kirchner could also serve as a model of such personal political leadership. Kirchner and her husband both supported the leftist Montonero movement that worked to overthrow María Estela Martínez de Perón, the second wife of Perón who served as a puppet president after his death. The military dictatorship specifically targeted Montoneros during the regime, but both Kirchners avoided politics during that time, returning in the late 1980s after the return to democracy. She served as senator while her husband was president, but he supported her candidacy for the next presidential term, which she won. She campaigned alongside the image of the Peronist heroine, Evita, Perón's first wife. She largely avoids addressing women's interests in any prominent way, but she appeals to the (largely poor) masses through social welfare programs, extensive subsidies for everything from electricity to transportation, and nationalistic actions like the appropriation of the oil company YPF. Her husband died in 2010, but she incorporated him as a central part of her reelection campaign. She referred to him often, vowing to continue to work toward his vision for the country. Even today, she wears black as a sign of mourning. Where Bachelet enjoys a very high approval rating, Kirchner is a remarkably polarizing figure: Argentines tend to be either ardent supporters or vocal opponents.

The two presidentas of the Southern Cone do share some common characteristics. Both are well educated, with professional degrees. Each participated in the promotion of democratic 
politics before or during the dictatorships in their respective countries, and entered politics soon after redemocratization. They climbed up the ladders of traditional politics, moving toward more important positions. Bachelet's ascent was aided by her friendship with former Chilean president Ricardo Lagos, while Kirchner used her husband's popularity to launch herself into the presidency. Both Bachelet and Kirchner used both traditional and innovative techniques to gain political power. They maneuvered like any politician must, but they also stressed what they could offer the country as women. These two women are exceptional and overcame great barriers to reach such high political office in their countries, yet they are laying the groundwork necessary for women to access upper levels of politics in the future.

\section{Conclusion}

Women in Argentina and Chile have made great strides toward gender equality in access to formal politics. Women actively advocated for democratic states that include women in the decision-making process. As a result, women now occupy greater shares of the national legislatures and ministerial positions in both countries, but there is still room for further progress toward gender parity. The governments of both countries have also been led by women politicians. Despite this progress, women's roles and leadership opportunities within politics are still confined by the gender cultures of machismo and marianismo.

Studies indicate that the Latin American public actually votes for women candidates in part because of stereotypes of feminine qualities which the people believe will make women better leaders. This suggests that perceptions of women have not actually changed significantly. The acceptance of women politicians is based in the conception of a politics of difference which says that women are not the same as men, but different in a positive way. Such beliefs reinforce

norms of marianismo and have not necessarily resulted in greater acceptance of gender equality 
among the citizens of the Southern Cone. However, women's presence in politics does appear to be associated with a greater respect for women, even if it is because of their perceived differences rather than a notion of equality. This change in attitude toward gender has allowed for women to engage in politics and achieve substantive change in women's interests, such as greater access to reproductive healthcare and measures to prevent violence against women.

The presence of women in politics is not a sufficient condition for the development of gender equality in the Southern Cone. Reforms of the institutional structures that limit women's access to and constrain their ability to use political office are necessary to enhance the descriptive and substantive representation of women in politics. Only once these changes are made will women have equal access to the full decision-making process, giving them the opportunity to enact policies that can create substantive change for issues important to women and begin work toward changing public perceptions of women and their roles in society. 


\section{Bibliography}

Antrobus, Peggy. 2004. “A Decade for Women: UN Conferences, 1975-85.” In The Global Women's Movement: Origins, Issues and Strategies, 37-66. New York: Zed Books.

Alvarez, Sonia E. 2009. "Beyond NGO-ization? Reflections from Latin America." Development 52(2): $175-84$.

Araújo, Clara and Ana Isabel García. 2006. "Latin America: The Experience and the Impact of Quotas in Latin America.” In Women, Quotas, and Politics, edited by Drude Dahlerup, 83-111. New York: Routledge.

Bachelet, Michelle. 2010. "Bringing Women out of the Shadows." The Miami Herald, Nov. 9. Web. http://www.miamiherald.com/2010/11/09/1916080/bringing-women-out-of-theshadows.html.

Barrionuevo, Alexei. 2007. "Political Tango, Women in the Lead." The New York Times, November 4. http://www.nytimes.com/2007/11/04/weekinreview/04barrionuevo.html?_r=0.

BBC News. 2004. “Chile Introduces Right to Divorce.” BBC News, November 18. Retrieved from http://news.bbc.co.uk/2/hi/americas/4021427.stm.

Caivano, Joan M., and Thayer Hardwick. 2008. "Latin American Women in Movement: Changing Politics, Changing Minds." In Civil Society and Social Movements: Building Sustainable Democracies in Latin America, edited by Arthur L. Domike. 4: 265-300. Inter-American Development Bank.

Carmona, Ernesto. 2006. “¿Quién es quién en el gabinete de Bachelet?” Archivo Chile. CEME. Retrieved from http://www.archivochile.com/Chile_actual/04_gob/chact_gob0017.pdf. Comando Michelle Bachelet. 2013. Retrieved from http://michellebachelet.cl/. 
Dahlerup, Drude, ed. 2006. Women, Quotas, and Politics. New York: Routledge.

Edwards, Sam. 2013. “Chile's Low Female Political Participation Takes Center Stage.” The Santiago Times, March 22. http://www.santiagotimes.cl/chile/politics/25904-chiles-lowfemale-political-participation-takes-center-stage.

Feijoó, María del Carmen, and Marcela María Alejandra Nari. 1994. "Women and Democracy in Argentina." In The Women's Movement in Latin América: Participation and Democracy, edited by Jane S. Jaquette. Boulder: Westview Press.

Franceschet, Susan. 2001. "Women in Politics in Post-Transitional Democracies: The Chilean Case.” International Feminist Journal of Politics 3: 207-36.

Franceschet, Susan. 2005. Women and Politics in Chile. Boulder: Lynne Rienner Publishers, Inc. Franceschet, Susan, and Jennifer M. Piscopo. 2012. "Gender and Political Backgrounds in Argentina." In The Impact of Gender Quotas, edited by Susan Franceschet, Mona Lena Krook, and Jennifer M. Piscopo, 43-56. New York: Oxford University Press.

Gallardo, Eduardo. 2006. "Chile's President Elect Unveils Cabinet.” The Miami Herald, February 23. Retrieved from http://www.chile-usa.org/NewCABINET.htm.

Gil, Rosa Maria, and Carmen Inoa Vazquez. 1996. The Maria Paradox. New York: J.P. Putnam's Son.

Gobierno de Argentina. 2011. "Autoridades Nacionales.” Retrieved from http://www.argentina.gob.ar/pais/48-acerca-del-gobierno.php.

Gobierno de Chile. 2013. "Ministros." http://www.gobiernodechile.cl/ministros/. Gray, Tricia. 2003. "Electoral Gender Quotas: Lessons from Argentina and Chile.” Bulletin of Latin American Research 22(1): 52-78. 
Hensman, Rohini. 1996. “The Role of Women in Resistance to Political Authoritarianism in Latin America and South Asia.” In Women and Politics in the Third World, edited by Haleh Ashfar, 48-72. London: Routledge.

Htun, Mala. 2005. "Women in Political Power in Latin America." In Women in Parliament Beyond Numbers, edited by Julie Ballington and Azza Karam. Stockholm: International Institute for Democracy and Electoral Assistance (IDEA). 112-21. <http://www.idea.int/publications/wip2/>.

Htun, Mala, and Jennifer Piscopo. 2010. "Presence Without Empowerment? Women and Politics in Latin America and the Caribbean." Social Science Research Council: 1-24. Global Institute for Gender Research. http://www.gigronline.org/publications.aspx.

Hughes, Melanie M. 2009. "Armed Conflict, International Linkages, and Women's Parliamentary Representation in Developing Nations." Social Problems 56(1): 174-204.

Huneeus, Carlos. 2007. The Pinochet Regime. Translated by Lake Sagaris. Boulder: Lynne Rienner Publishers.

Hunt, Swanee, and Cristina Posa. 2001. "Women Waging Peace.” Foreign Policy, 124: 38-47. International Institute for Democracy and Electoral Assistance (IDEA). 2010. "Politics and Parties: Without Equality, Far from Parity.” Last modified March 8. Retrieved from http://www.idea.int/gender/without_equality.cfm.

Inter-Parliamentary Union (IPU). 2013. "Women in National Parliaments.” Last modified February 1. Retrieved from http://www.ipu.org/wmn-e/classif.htm.

Jaquette, Jane S. 1997. "Women in Power: From Tokenism to Critical Mass.” Foreign Policy 108: $23-37$. 
Kim, Eunice. 2013. "Beyond Statistics: the Bleak State of Gender Violence in Chile." The Santiago Times, March 25. http://www.santiagotimes.cl/opinion/special-reports/25911-beyond-statistics-the-bleak-state-of-gender-violence-in-chile.

Latinobarómetro Corporation. 2013. “Online Data Analysis.” Retrieved from http://www.latinobarometro.org/latino/LATAnalizeIndex.jsp.

Luna, Lola G. 2003. "Los Movimientos de Mujeres Como la Otra Cara de la Política: Genero, Exclusión e Inclusión en el Caso Latinoamericano." In Los movimientos de mujeres en América Latina y la renovación de la historia política, 45-63. Santiago de Cali: La Manzana De La Discordia. http://www.lolagluna.com/publicaciones/MovimientoMujeres/4LosMovimientosMujeres. pdf

Matland, Richard E. 2006. "Electoral Quotas: Frequency and Effectiveness." In Women, Quotas, and Politics, edited by Drude Dahlerup, 275-292. New York: Routledge.

Merriam-Webster. 2013. "Machismo.” Retrieved from http://www.merriamwebster.com/dictionary/machismo.

Molyneux, Maxine. 2001. "Género y Ciudadanía en América Latina: Cuestiones Históricas y Contemporáneas." Debate Feminista 23(12): 3-66. http://www.cnm.gov.ar/generarigualdad/attachments/article/191/Genero_y_ciudadania_e n_America_Latina.pdf.

Pérez, Paula Andrea Pereda. 2011. "Female Politicians in Chile: Unfolding the Meanings and Implications for Chilean Politics in the Twenty-First Century." PhD diss., Victoria University of Wellington. 
Paxton, Pamela, and Melanie Hughes. 2007. Women, Politics, and Power: A Global Perspective. Thousand Oaks: Pine Forge Press.

Real Academia Española. 2001. "Machismo.” Retrieved from http://lema.rae.es/drae/?val=machismo.

Reel, Monte. 2007. "South America Ushers in the Era of La Presidenta." The Washington Post, October 31. http://www.washingtonpost.com/wpdyn/content/article/2007/10/30/AR2007103002223.html?sid=ST2007103101478.

Rivas, M. Fernanda. 2008. “An Experiment on Corruption and Gender.” Retrieved from http://www.ugr.es/ teoriahe/RePEc/gra/wpaper/thepapers08_10.pdf.

Seager, John. 2009. The Penguin Atlas of Women in the World. New York: Penguin Group.

Shepherd, Laura. 2010. "Sex of Gender? Bodies in World Politics and Why Gender Matters." In Gender Matters in Global Politics: A Feminist Introduction to International Relations. 316. New York: Routledge.

Skármeta, Antonio. 2012. "The Women Politicians of Chile Set to Take Their Country Back." Clarin, November 11. Retrieved from http://worldcrunch.com/opinion-analysis/thewomen-politicians-of-chile-set-to-take-their-country-back/skarmeta-santiago-labbebachelet/c7s10061/\#.UWaSLrUsm8C.

Skjelsbaek, Inger. 2001. "Is Femininity Inherently Peaceful? The Construction of Femininity in War.” In Gender, Peace and Conflict, edited by Inger Skjelsbæk and Dan Smith, 47-68, The International Peace Research Institute, Oslo (PRIO). London: SAGE Publications Ltd., 2001. doi: 10.4135/9781446220290.n4.

Starr, Alexandra. 2006. “A Woman's Place is in the Presidential Mansion.” The Slate Group, January 4. Retrieved from 
http://www.slate.com/articles/news_and_politics/foreigners/2006/01/a_womans_place_is in the presidential_mansion.html.

Swamy, Anand, Stephen Knack, Young Lee, and Omar Azfar. 2001. "Gender and Corruption." Journal of Development Economics 64 (1): 25-55.

United Nations Development Programme (UNDP). 2013. "The Millennium Development Goals: Eight Goals for 2015." http://www.undp.org/content/undp/en/home/mdgoverview.html. United Nations. 2000. "Convention on the Elimination of All Forms of Discrimination Against Women.” Retrieved from http://www.un.org/womenwatch/daw/cedaw/text/econvention.htm. United Nations Department of Public Information (UNDPI). 2000. “The Four Global Women's Conferences: 1975 - 1995". http://www.idea.int/gender/without_equality.cfm.

UN Women. 2011a. “About UN Women.” Retrieved from http://www.unwomen.org/aboutus/about-un-women/.

UN Women. 2011b. "Biographical Sketch: Michelle Bachelet.” Retrieved from http://www.unwomen.org/about-us/directorate/former-ed-michelle-bachelet/biographicalsketch-michelle-bachelet/.

Waylen, Georgina. 1996. "The Third World and Development." In Gender in Third World Politics, 24-45. Boulder, Colorado: Lynne Rienner Publishers, Inc.

Zetterberg, Pär. 2009. "Do Gender Quotas Foster Women's Political Engagement? Lessons from Latin America." Political Research Quarterly 62(4): 715-30. 